\title{
Evaluation Of Curriculum Implementation On Leadership Training Level IV In Human Resources Development Agency Of North Sumatera Province
}

\author{
Suriya Jaya \\ Human Resorces Development Agency of North Sumatera Province, Indonesia
}

\begin{abstract}
The aim ofthis study is to find how the evaluation of the Curriculum Leadership Training Level IV implementated in Human Resources Development Agency (BPSDM) of North Sumatra Province. The focus of the research is "To Evaluate the implementation of Curriculum Leadership Training Level IV in Human Resources Development Agency", using qualitative methods. Data collection technique were interview, observation, document study, analysis of data using an interactive model of Miles and Huberman, data validity checked by Lincoln and Guba. The research found: First, based on the evaluation, there were found some weakness such as: the lack of learning materials, behavioral attitude of the organizers, facilities and infrastructure, dicipline of trainers. Second, the evaluation of curriculum implementation had not been fully Regulation of the Public Administration Institute of the Republic of Indonesia (Perkalan-RI) number 22 of 2014. Third, the evaluation phase of the institution take collective decisions on the success of the training participants, an assessment of the lecturers, LAN-RI monitoring of the implementation of Leadership Training Level IV and learning plan of trainer. Fourth, the evaluation class phase to ensure the participants training designing innovation and changed management. Therefore,Human Resources Development Agency (BPSDM) of North Sumatra Province should follow up fully the weakness Leadeship Training Level IV based on the evaluation. Participants avaluation of training Leadership Training Level IV participants should also assess the attitudes of other positive behaviors, such as integrity, discipline, responsibility, morality required by leaders of change.
\end{abstract}

Keywords: evaluation, curriculum implementation, leadership training

\section{BACKGROUND}

To organize leadership training level IV at the first time, BPSDM of North Sumatera (BPSDM Provsu) guided curriculum of Public Administration Institute of the Republic of Indonesia (LAN-RI) number 13 of 2013 about Guidelines for the Implementation of the leadership training Level IV called "Leadership Training Level IV New Pattern Curriculum". The curriculum is guided nationally by an accredited training institution which organizes training under the guidance LAN-RI in Jakarta.The uniqueness of leadership training level IV new pattern curriculum is the evaluation not only measures the ability of the training participants to write papers of change projects textually, but more than that, the participants demanded to be able to implement their change project into the real situation of work in their office at the stage of Leadership Laboratory to achieve the standard of leadership training level IV competency as a leader of change in their institutions in accordance duties and functions in the areas of work. To measure the participant's success in achieving the competency standards of Leadership training level IV, is measured in an integrated manner through seminars evaluation of changes project design and change project management by evaluator team, to then become the basis for management board in making decision the success of leadership training level IV participants. To carry out all these evaluations, required management of leadership training level IV through evaluation of the leadership training level IV curriculum implementation.The research question in this study is: "How process and result of evaluation the leadership training curriculum implementation in BPSDM Provsu". This question will be explored in social settings parameters BPSDM Provsu include background, actors, events, and processes.

\section{LITERATURE REVIEW}

To determine the successful of leadership training level IV implementation needed feedback through evaluations that can be known strength and weakness of its implementation. Through the evaluation can make many aspects of excellence to be maintained, while aspects of the weakness can be followed from not happening again in the future. By evaluating the implementation of the curriculum can determine the success of the implementation of leadership training level IV of trainers, the training participants, implementation, infrastructure aspects. According Mardaphi (2012:28) "the results of evaluation of education is very useful information for managers of national and local level, providing accurate and detailed information for the 
improvement of the quality of education".Based on these opinions, evaluations are urgent matters and at the same time has an important meaning because it is used as an input detailed information for efforts to manage and improve the quality of education better in the future. It stated that evaluatio has important meaning because it can be served as a foundation to set more appropriate policy by leaders because the result of evaluation has the function as a data and information based on the fact.

\section{Definition of the evaluation of curriculum implementation}

According to Arikunto (2013: 39) "the evaluation is intended to measure the achievement of goals, preparing to move evaluation of objectives, evaluation tailored to the learning activities are carried out". Evaluation according to the opinion of an effort to see the success of achieving goals, whether the goals have been formulated in the planning has been able to achieve optimal results, the measurements are made against the objectives that have been formulated so as not to deviate from the mean achievement of learning objectives. Thus the purpose of the evaluation is a compass showing the direction in terms of what purpose it will be evaluated. Therefore evaluation should be consistent measure of success in achieving objectives such as learning objectives in the lesson planning. Rusman (2011: 95) evaluation included components needs analysis and feasibility study as a first step curriculum design, planning and development in accordance with the needs of educational institutions, the learning process as a step curriculum implementation, curriculum revision is based on the evaluation of weakness, succesful, adherence to the curriculum, and curriculumresearch for curriculum development.Based on the components of the curriculum evaluation, one of the components of curriculum evaluation is a learning process. Thus the evaluation of curriculum implementation included the evaluation of the implementation of learning, so talk about the evaluation of curriculum implementation is related to the evaluation of learning. Also, the curriculum evaluation is done after the planning is implemented in learning to determine whether the goals are implemented according to the curriculum can be achieved in the learning process.Menurut Hussein (2011: 14) educational goals can be achieved other than through a curriculum that is reliable and valid, also through a proper evaluation of the process to renew and fulfill social needs required. The effectiveness of a curriculum can be seen from the implementation that is through learning that determined whether a curriculum choice needs to be revised or maintained. Thus the evaluation results as the basis for a decision on whether or not the curriculum updated as needed.

Evaluation of teaching and learning by Dimyati and Mudjiono (2009: 192), "is the process to determine the value of teaching and learning implemented through the assessment or measurement of learning and teaching." Based on the definition of the evaluation of teaching and learning that they thinks there are two types of evaluation, namely the evaluation of learning outcomes and evaluation of learning process. Evaluation of learning outcome emphasize the acquisition of information acquisition how far learners master the teaching objectives set out in the learning plan after teaching-learning process. While the evaluation of learning process is a series of systematic processes to obtain information about the effectiveness of the learning process to assist learners in mastering teaching purposes. Evaluation of learning outcomes and evaluation learning process carried out in the context of teaching and learning as part of the educational process, therefore evaluation of learning outcomes and evaluation of learning process are educational evaluation.

Based on the basic concept of evaluation above, It can be concluded that the evaluation of the implementation of the curriculum is an attempt to see how far the success of the implementation of the curriculum so as to determine further action, if needed repairs to the weakness that occurs, strengthening towards excellence in all aspects of planning, implementation, and towards supporting resources implementation curriculum. In Leadership training level IV contexts, evaluation is very important to determine the effectiveness of the planning in institutional stage by management board and classphases by trainers, the effectiveness of curriculum implementation ininstitutional stage by management board and classphases by trainers, especially trainer's competence in learning process, the effectiveness of the infrastructure used.

\section{The principle and direction of curriculum implementation evaluation}

It is not possible to improve the quality of education is done through improving the quality of learning and the quality assessment system, because of the quality of learning that is planned to be measureble, so obviously strengths and weaknesof its implementation. Efforts to improve the quality of training, ideally accompanied by improving the teaching-learning and evaluation or assessment.

According Mardapi (2010: 11) the benefits of evaluation are as follows: "the assessment system used by each educational unit must be able to: (a) provide accurate information, (b) to encourage students to learn, (c) motivate educators to teach (d) increase the performance of the institution; (E) improving the quality of education ". Thus the results of the evaluation should be able to inform the results of proper evaluation of the goals and what have not achieved by the training participants to be provided as input for trainers whetherthe learning strategies conducted so far has been effective or still need to be improved, so It can be to encourage the training participants increase learning more diligently than ever. When the trainers know the results of the 
assessment carried out, then It is expected to be feedback to enhance and improve teaching strategies do, so it is expected to increase the motivation of the training participants and trainers. It is expected to have an impact on increasing the performance of the organizers of the training, so the training assessment system as evaluation of curriculum implementation conducted push to improve the quality of education and training.

\section{The Evaluation Objective's of Curriculum Implementation in a Learning Activity}

To determine the successful the implementation of curriculum, it should be evaluated in order to determine the level of success and drawbacks so as to determine further action. Wahyudin (2014: 103) concludes that the purpose of the evaluation is to see the ongoing implementation process as a control task, whether the evaluation was according to plan and function improvements to the deficiencies in the implementation of the curriculum and know the end result is achieved. Thus evaluation can be conducted on an ongoing process to control whether the plan is consistently implemented, carried out to find out the results of implementation, would be used to improve the weaknesses in the implementation stage.

\section{RESEARCH METHODOLOGY}

This study uses qualitative naturalistic. Data collection techniques using the technique of interview, observation and document study. Sampling design is used purposive sampling, data is analysed by using interactive model of Miles and Huberman, namely data reduction, data presentation, drawing conclusions. This research method using qualitative methods naturalistic chosen on the basis of data that will be explored the data that will describe the complex social situation in such a way that the concrete social phenomena. Source of data to be used are the human and non-human. Source of human data includes social situation in context described until the discovery of the behavior of the actors, namely Head of Training Agency of North Sumatera Province, Head of Training Agency, Head of Area and Sub Area of Division of Training hierarchical arrangements, Head of Administrative, staff Sub Division hierarchical arrangements, chairman/deputy chairman of the Group Trainer in Agency Training of North Sumatera Province, Chairman of the Forum Trainer of North Sumatra Province Secretary of Forum Trainer, trainer in Training Agency of North Sumatera Province. While nonhuman data sources are documents and physical and non-physical environment.

\section{RESULTS}

\section{The Function of curriculum implementation evaluation in learning activities}

To determine the effectiveness of the implementation of leadership training level IV, BPSDM Provsu conduct an evaluation to determine how far the success of leadership training level IV in planning of the curriculum implementation and execution of the curriculum implementation that has been done, as well as an evaluation of the results of the evaluation of the curriculum implementation to get an overview of advantages that needto be preserved and weaknesses that need to be improved immediately so the leadership training level IV can be further better in the future.

\section{a. The Function of Evaluation curriculum implementation planning}

Perkalan-RI Number13 of 2013 about Guidelines for the Implementation of leadership training level IV- refurbished with Perkalan Number 22 of 2014. The main body amendments eliminate the ratings aspect attitude-behavior in Perkalan Number 13 of 2013 or annul the assessment of the behavioral aspects of the training participants (integrity, ethics, discipline, cooperation, initiative) turn into liabilities of leadership training level participants. They are not justified not attended more than nine hours of lessons during their training process. Other evaluation aspects according to Perkalan Number 22 of 2014 is the evaluation of the training participants, evaluation of lecturers by the participants of the training, evaluation of lecturers by a team of evaluators, evaluation of the execution, post-training evaluation. In addition to the evaluation of the training participants has not changed, it remains an evaluation rules that must be followed in leadership training level IV. Here is a description of the evaluation results of the function of curriculum implementation planning in institutional stage and class stage. Evaluation of curriculum implementation planning in institutional stage included an evaluation by the LAN-RI against leadership training level IV in BPSDM Provsu, trainers evaluation by a team of evaluators and evaluation of facilities and infrastructure.

Implementation of leadership training level IV evaluated by LAN-RI in the form of monitoring or assessment in the form of control to function as an institution builder training. In line with that LAN-RI performs three roles atonce. First, the role of evaluation in the measurement and assessment of learning outcomes of training in the class stage. Second, carry out the function of controlling of the operation of the leadership training level IV. Third, controlling of trainer's lesson planning in the form of lesson plan, design of learning, and exposure in the form of power point material. Monitoring LAN-RI to lesson plan and design of learning, as well as exposure material prepared by previous lecturers informed by BPSDM Provsu through a letter from the Chief of BPSDM Provsu to trainers for purposes of monitoring from LAN-RI. 
According to Terry and Leslie W.Rue (1982: 107) "assessment including efforts to control, which evaluates the implementation of the activities, if necessary to improve activities that have been implemented to get certainty achieve planned results". Based on Terry and Leslie opinion there are three objectives of assessment. First, to determine the effectiveness of on going activities whether in accordance with established standards. Second, make a decision or to consider whether it is important or no to improve the weaknesses found in the execution of activities. Third, to know the success of the activities planned beforehand.

Daft (2003: 525) calls controlling in terms of control of organizational (organizational control), which is a systematic process used by managers to regulate the activities of organizational to make them consistent with the expectations established in the plan, targets and performance standards.

Based on the meaning of control above, the control of activities is an effort to get feedback on the activity to determine the success of a plan. The goal is to obtain information on the activities that will be and have been implemented in order to improve in the future, with the implementation it is expected the compare of the implementation of activities with one another, can encourage more efficient operational activities.

LAN-RI monitoring of the leadership training IV, is included as a assessor or an examiner in project design changes seminars and seminars of project implementation changes of leadrship training level IV in BPSDM Provsu . LAN-RI represented by P2KP LAN-Aceh, participated as a team of evaluators in seminar of change project implementation and the final determination of the training partcipansts graduation and conduct monitoring of leadership training level IV in BPSDM Provsu.

The essence of monitoring or controlling is a monitoring tool for the team leader to know whether plans have been drawn up and prepared in advance can be implemented or not. Without monitoring, team leader will not know the activities carried out and has been delegated to subordinates can be up to the job that has been targeted. Monitoring or controlling performed can be directed to measure the performance achievements fact, to comparethe fact of performance with a minimum limit that has been set, perform concrete action deemed necessary to result in a substandard performance achievements or work that does not comply with the plan.

Daft (2008: 525) suggests three forms of control. First, feed forward control is a preventive controls to identify and prevent errors work. Second, continuous control, which oversee the activities of the staff on an ongoing basis so that they remain consistent with the rules and regulations of performance standards. Third, feedback control, which controls focus on organizational outcomes, quality of service is the end of service.

Based on the three types of the control, monitoring by LAN-RI to BPSDM Provsu is a category of feedback control, because it is done at the end of leadership training level IV and evaluation institutional phase to the result of the evaluation of class phase by a team of evaluators to know BPSDM Provsu whether it has been based on the governance of education and training based guidelines for the implementation of leadership training level IV that has been published by LAN-RI according to Perkalan-RI Number 13 of 2013 along with a set of other rules supporting such changes in guidelines for evaluation of the success of the leadership training level IV participants and other supporting guidelines. Monitoring can be a tool to find information and feedback on the management functions of implementation leadership training level IV starting from the planning functions of curriculum implementation, the executing of the curriculum, and evaluation of curriculum implementation, whether entirely been able to meet the standards outlined limits.

Based Perkalan-RI Number 13 of 2013 and Perkalan-RI Number 22 of 2014, an evaluation of lecturers by a team evaluators is the implementation of the certificate of competence of which includes management capabilities learning implementation in terms of the management of the learning plan through making design of learning, a lesson plan, exposure material, and teaching materials.

According Mustari (2015: 95) "evaluation of lecturers is very important, trainer is a functional group that has a very large role in the formation of mental attitude and intellectual training participants". The trainers is a dominant factor and the most important in the training because it is the cutting edge of learning that control the learning resources in the curriculum implementation of leadership training level IV, so it is need to know how the quality in the preparation, and in the implementation of learning.

In fact the evaluation of lecturers by a team of evaluators is not implemented by BPSDM Provsu in leadership training level IV. Ideally, this evaluation is performed to determine more clearly the ability of lecturers according to their competencies to manage the planning and implementation of learning lessons. Assessment can push to improve the quality of education. According to Mardaphi (2012: 11) "The assessment system used at least be able to (a) provide accurate information, (b) to encourage students to learn, (c) motivate educators to teach (d) increasing the institution's performance; (E) improving the quality of education ".

With the evaluation of lecturers by a team of evaluators at least be able to know where the strengths and weaknesses of various technical terms appropriately in learning, a driving force for the better trainers in learning, to motivate the training participants to improve the quality of teaching-learning and performace of BPSDM Provsu in the future.

Most of the training participants gave less value in the aspect of infrastructure included subcomponents of dormitories, classrooms, training aids, cleanliness, security and arrangement, consumption, 
although the conclusion of the satisfaction of 30 (thirty participants) to leadership training level IV score 75,75 (good). Based on the result, we can know the level of satisfaction of training participants to leadership training level IV is an average well, but each component is still expressed less training participants. For that BPSDM Provsu can ideally follow up assessment training participants to the lack of facilities and infrastructure. According Mustari (2015: 121) improve service training in dormitories, classrooms, training aids, hygiene, security, order, and consumption of leadership training level IV, and structuring the management of facilities and infrastructure, from planning (analysis of needs), procurement, inventory, distribution, using, maintenance, extermination and accountability, chattels and immovable. Based on these conditions, efforts to be made by the BPSDM Provsu, it is needed to map the aspects of infrastructure are prioritized based on the urgency and relevance of the needs of training, to collect data on assets of any kind of training, so as to immediately cover the lack of infrastructure through the procurement, distribution, leverage, do treatment, in accordance with existing regulations.

Evaluation of curriculum implementation planning in class stage includes an evaluation of the change project proposal and evaluation of training execution as a form of evaluation of the quality of leadership training level IV implementation in the BPSDM Provsu. Evaluation of design innovation change projects is considered representative of the entire training eye served lecturers and participants followed the training, conducted through seminars of innovation design or seminar of change project proposal in the classroom, and evaluation of change management or seminar implementation of project change, as well as the final evaluation of the training participants in leadership conference room.

Regulation No. 22 of 2014 determining the graduation of leadership training level IV focuses on aspects of change project, components consist of a $40 \%$ innovation planning, $60 \%$ change management. Innovation Planning component consists of indicators : $10 \%$ type of change, $10 \%$ scope of benefits changes, $10 \%$ the clarity of changes stage, $10 \%$ stakeholders mapping. Evaluation for training participants integrated based on to the extent of the success of the training participants in drafting and implementing change projects. The whole learning agenda in the end is directed to the ability of the training participants develop and implement change projects. The success of training participants in preparing project change design is a reflection of the success of the entire agenda of training material.

In the discussion of evaluation of the organization are covered in the evaluation of curriculum implementation planning in the class stage is the evaluation of the learning material. Eight participants, or $26.7 \%$ of training participants assessing their lack of learning material covering availability, useful, relevance to the task of learning materials. Overall, the evaluation of the implementation of the training participants are summarized in the final report of leadership training level IV that consist recapitulation of the training participants evaluation to trainers, organizers, the availability of learning materials, facilities and infrastructure. Training on the implementation of corresponding average value obtained 74.44 (seventy-four point forty four) or good categories. However nine participants of the training or 30\% give less value to the organizers, included the attitude and behavior, communications and services, readiness and alertness. Because of the assessment category is good, for this Provsu Training Agency does not conduct follow-up in particular, only inform in the meeting that the situation of education and training by the committee can be increased.

\section{b. The Evaluation Function of Curriculum Implementation in Learning Activities.}

The evaluation function evaluation of curriculum implementation in learning activities that will be presented here include curriculum implementation in insitutional phase and evaluation of curriculum implementation in class stage. Evaluation of curriculum implementation in class phase cover change management evaluation, evaluation of lecturers by the participants of the training, evaluation of the evaluation result.

Evaluation at this stage in the form of post-training evaluation and the evaluation of the organizers. Post-training evaluation based on Perkalan-RI Number 13 of 2013, the evaluation through mechanisms and procedures between six to twelve (12) months after the ending of training, post-training evaluation to determine and quantify the level of utilization of alumni training in structural position; developmental changes have been implemented, the plan changes that will be implemented; the level of alumni performance improvement; the increased level of agency performance in alumni organization unit.

Post-training evaluation conducted by the organizers of the training in cooperation with agency personnel unit. Post-training evaluation results submitted by the organizers to the official staff development alumni, the alumni leadership of the agency, institution builder controller training and training institutions; builder training institutions using post-training evaluation results as input for further improvement of the training program. Post-training evaluation conducted jointly by a team using post-training evaluation in the form number 14. The form is quite important to map the effectiveness of leadership training level IV, in order to obtain concrete data on the extent of organized training and training participants followed a positive impact on training institutions as the positive impact of alumni of training participants who received the training. 
The function curriculum implementation in classroom phase included the evaluation of change management, evaluation of lecturers by the participants of the training. Evaluation of change management is an evaluation to measure the ability of the training participants to execute the project design changes that have been drawn as an action plan at their respective institution, while the evaluation of lecturers by the participants of the training is an evaluation of the lecturers in the classroom when teaching.

Based LAN-RI Regulation number 22 of 2014, it is determines the graduation of leadership training level IV focus on aspects of the changes project, the change management component weight of $60 \%$. Change management component consists of subcomponents indicator of the number of activities to mobilize supporting in the form the ability to empower the team of $15 \%$, a statement of support of $15 \%$ evidenced by written support, achievements of phase change of $30 \%$ in the form of milestones implementation.

Implementation of changes project in own institution is implemented fully and completely guided by the change project design that have been prepared and received recognition by the authorities in a seminar on changes to project design was considered to have proven its feasibility to be used as a proposal or change project design, the indicator of success is when the change project design can be implemented at this stage of Leadership Laboratory.

Based on the evaluation through the innovation design seminar and also change management, both of which are intended to measure the evaluation of the competence of the training participants realize or not realize the goals, accomplishments order to position participants of the training, gathered information of effectiveness in trainer's teaching and learning strategies.

Correspondingly Davis (1991: 294) evaluation is a planned to improve lesson plans and learning resources to consider further exploration. This is consistent with the nature of the change project seminar, on the one hand as an attempt to measure the ability of the training participants in charge of the of innovation desig in the project proposal and operationalize the changes planninnng to achieve its objectives through the management of change by implementing appropriate changes in project design or phasing activity milestones. The evaluation of the management of change through the implementation of a change project means measuring the performance of the implementation of innovation design in change project proposal. Known implementation performance, because the project implementation phase change in the laboratory leadership training participants carry out activities changes project design is still shaped paper work as the end result of training activity period on campus.

According perkalan-RI Number 22 of 2014, the aspects considered in the evaluation of lecturers by the the training participants included systematic presentation, the ability to present, punctuality and attendance, use of methods and means of training, attitude and behavior, to answer the questions of the participants, the use of language, providing motivation to the participants, neatness of dress and cooperation among lecturers.

Evaluation of training participants to their trainers in leadership training level IV is done by providing a form that contains trainers assessment. Training participants fill out a form to assess all the trainers and return it to the committee through the class picket. Based on the recapitulation of the whole assessment training participants to all trainers for all training materials of leadership training level IV,the result shown that the highest average score was 88.90 (eighty-eight point ninety) with good category for the training materials of pillars nationality, while the lowest value is 74.20 (seventy-four point twenty) in the change project change design materials. The average value of trainer is 81.49 (eighty one point forty nine) category excellent. It is based on the criteria scores are listed as noted below: 81-100 (excellent), 61-80 (good), 41-60 (enough), 21-40 (less), $0-20$ (poor). The lowest value is in the ability to present and the ability to motivate, each value of 68 (sixty eight). However, although the average value of 12 (twelve) of trainers total overall is excellent, there is the lowest value on training materials of Integrity in aspects of the capability of presenting, training materials of the State Administration System (SANRI) in the aspect of giving motivation to the participants of the training. Both of the training materials and the aspects obtain the value of 68 (sixty eight) in good category. However it required attention for following-up beacause of under the average value of the all lecturers with value 81.49 (eighty one point forty nine).

Start from the results of the evaluation of lecturers by the participants of the training, there is still training participants who are not satisfied with the timeliness of trainers during the learning process, It meant that not all training participants were satisfied with the learning performance of trainers in the process of timing as the substance of training materials being occupied. Four of the training participants or $13.3 \%$ give less category to trainers in terms of availability and timeliness.

Problems of trainers aspects (availability, timeliness), trainer is an important aspect of human resources that played an important role in achieving the goals of training, bound with an attitude that can be emulated behavior in accordance with the personal competence to be possessed. Therefore, It is needed attention to obedience trainers in following the training learning schedule that containing a predetermined time allocation.

In front of the training participants in the learning process, trainer,s role are to educate, teach, and train, become leaders, role models. In Law Number 20 of 2003 on National Education System, trainer is educator 
other than teacher, lecturer, tutor, instructor. Therefore ideally trainers have a quality standard of personality such as responsible, authoritative, independent, and discipline. Factors such as timeliness discipline in teachinglearning ofleadership training level IV need special attention because it involves aspects of personal competence in attitude and behavior of trainers that should be emulated. That is, ideally trainer personality can give a role model, the personality of sympathy and empathy. According to Basri and Rusdiana (2015: 95) "trainers personality should reflect the personality of simplicity, discipline and sportsmanship, representative, accomodative, non-discriminative, communicate their thoughts, applying andragogy, mastering the use of teaching aids".

For trainers weakness aspects in terms of punctuality, the ability to present and provide motivation in the learning process in leadership training level IV, BPSDM Provsu followed up by conveying the information trainer's evaluation results in a meeting. That is, BPSDM Provsu has not been followed this up completely.

Based on data from the evaluation of trainer leadership training level IV, the aspects that need attention by BPSDM Provsu in organizing training is the aspect of learning materials (availability, benefits, relevance to the task), aspect of trainers (availability, timeliness discipline), aspects of the organizer (attitudes and behavior, communications and services, readiness and alertness).

\section{c. Evaluation of the results of the evaluation function}

In the context of the evaluation of learning outcomes, this stage is a stage of institutional evaluation, carried out on the results of evaluation by a team of evaluators class stage, the follow-up is to discuss the assessment results in evaluations through workshops and seminars of changeproject implementation or leadership laboratoy. Only participants who have successfully implemented the projects based on milestone in their institutions as a whole that declared has operational leadership competence and passed in leadership training level IV. If there is the output part of the unfinished milestone implemented by the training participants, it meant the participant postponed for graduation.

The results of the evaluation of the success of the training participants through seminars of change project design and implementation of changes project brought to the forum to management board meeting to discuss whether the training participants passed, delayed to pass, or do not pass based on value given by mentor, values from assessor, outlook of coach that has recapitulated in a specific format. The evaluation meeting attended by the head of BPSDM Provsu and management board, and LAN RI represented P2KP LAN-Aceh, pay attention to the values given by each assessor, recapitulation, the written description of the coach to the training participants. Evaluation at this institutional stagealso decides success or failure of the training participants based on measurements of the individual participants of the training. According Hamalik (2005: 117) this decision is important in this stage as suggested in training leaders make decisions about the learning outcomes of the exercise as part of other decisions such as the decision of the lecturers, and the implementation of the program.

Form of evaluation done at the institution, tends to make an assessment, if not done carefully to get stuck into votes compared to the measurement are subjective, as determined by the appraiser to evaluate the measurement is based class stage. Based on the results of measurements on the class stage in the form of qualification class and score, so it can be taken a decision on the graduation of the training as a form of team leader decisions about the success of the training participants. At this institutional stage also, BPSDM Provsu shall take decisions by an assessment to participants whether the training participants passed, delayed to pass, or do not pass by the collective decision of the meeting participants in institutional stage evaluation.

Based on the discussion of the evaluation of learning outcomes leadership training level IV in institutional and class stage, it can be concluded that the evaluation of learning outcomes is essentially a decision-making process succesful or unsuccesful to the training participant in the leadership training level IV based on the criteria set out in the curriculum LAN-RI. Evaluation is a decision for the activities that are exposed to multiple alternative that is successful or unsuccessful participants Training. Decision-making by Terry and Leslie (1982: 8) "is an activity choose an alternative from two or more alternatives exist to determine the direction of the objectives to be achieved."

The opinion explain the importance of achieving objectives targetted in opting against something, because the decision is to proceed activities, geared towards clarity where the goal will be directed. In decisionmaking is not only faced with two choices but few options. In the evaluation of learning outcomes of leadership training level IV training there are two alternatives to the training participants, ie, successful or unsuccessful, or three alternatives to the participants of the training are passed, delayed to pass, or do not pass based on the criteria decision. According to Williams (2001: 194) "decision is a basic measure that is used to guide the deliberations and decisions". The basic measure of success or failure according to the number that has been set, pending means pass but given a certain time of several days to meet the shortage achievement of milestones and the implementation of the change project, do not pass the meant the participant is fail because of the 
achievements of the numbers of evaluation does not meet the minimum limit according to criteria which has been set.

In accordance with aspects that are measured and assessed through evaluation of the training participants through the ability toinnovation design and innovation management show the tendency of cognitive domains, namely putting development of intellectual skills training participants in a dominant position, while aspects of the affective domain received less attention because it is only assessed from obedience to do not attended more than nine hours of lessons. Here occurred contradictory between measurement and assessment in the evaluation system of the training with the ideals of bureaucratic reform. Morning assembly speech text governor of North Sumatra (2016: 1-3) said that in line with Law Number 5 of 2014 stated in the new paradigm of government officers development are directed to employees of the State Civil Apparatus (ASN) professional in a new perspective to realize good governance is based on competence, so that able to realize public goods and service, is able to face the challenges of the globalization phenomenon loaded with competence, transparency, intensity information is very high, so that government officials must be one of the reliable instrument, tough, professional, at all levels and hierarchy, worth basis, obedient ethics profession, political intervention-free, clean of corruption, collusion, nepotism since the recruitment, training, and career development, to full service.

On the other hand evaluation system of leadership training level IV overlook the behavioral aspects as supporting instruments that are needed to build the figure of government leaders that positive personality to be able to build good governance. To realize the figure of ASN as stipulated in Law No. 5 of 2014 of integrity, honesty, discipline, clean of corruption, are indispensable system training that emphasizes a balance between aspects of cognitive domain and affective domain, so there is no imbalance between education on the one hand with personality training participants in the other party in order to fulfill their duty correctly bureaucratic reform.

Based on the discussion of the evaluation of curriculum implementation leadership training level IV as above, it is known that the evaluation of curriculum implementation leadership training level IV in institutional stage $y$ the LAN-RI at the end of the implementation of the training to determine the final outcome implementation of the training in the form of feedback control. This control is an organizational control to regulate the activities of the organization, its shape needs to be expanded not only in the form of feedback control, but can be expanded into a form feed forward control, and continuous control. Thus the proposition which arises here is, if the evaluation of curriculum training implementation in insitutional stage expanded in the form of feedback control, control of the feed forward control continuously, it will be carried out preventive control starting from planning phase of the training to prevent errors work, carried out continuous control, so that organizational activities in the training remains consistent with the principles and standards of performance, and the implementation of final results focus on control work of the organization as a final product quality of service.

\section{Conclusion:}

\section{CONCLUSION AND SUGGESTION}

1. Evaluation of the curriculum implementation of the leadership training level IV included an evaluation of learning outcomes of the training participants, evaluation of lecturers by the participants of the training, evaluation by a team of evaluators trainers, post-training evaluation. Based on existing data search found, there were not found trainers evaluated by a team of evaluators, and post-training evaluation. Evaluation of curriculum implementation in leadership training level IV categorized into evaluation of curriculum planning, evaluation of curriculum implementation, and evaluation of the evaluation results of the curriculum implementation in the learning activity.

2. Evaluation of curriculum planning implementation in institutional phase included the evaluation and monitoring by LAN RI, perform organizational tasks organizationally that control by managers to perform feedback control on the quality of the end product of training so that decision-making in leadership training level IV is consistent with the plans, standards, and outcomes performance.

3. Evaluation of curriculum planning implementation in class phase included the evaluation of seminar innovation design by training participants, and training participants evaluation on executing the leadership training level IV. Evaluation of design innovation give the numbers qualifying and score on the ability to design innovative training participants. Evaluation of training participants on the implementation of leadership training level IV included learning materials relating to the availability, benefits, relevance to the task of learning materials and infrastructure. Evaluation of curriculum implementation is the evaluation class stage included the seminar of change management and evaluation of the trainer by training participants. Evaluation of change management performance measure the performance of change project design implementation or as a end result of activity.

4. Evaluation of the evaluation results is carried out by management board and LAN-RI at this stage of the institution included assessment of the evaluation results of the class phase by coach, mentor, and speakers as 
the team evaluator on seminar innovation design and change management, to determine the rank and graduation of training participants.

\section{Suggestion}

1. Evaluation of the training participants should not only to measure and assess the participants' ability to innovation design and change management, but also assess other aspects of positive behavioral attitude, as leaders of change as the standard of competence the training targets in addition to professional must have integrity, discipline, responsible, noble to be used as a source of strength to lead operational bureaucratic reforms in the institution in accordance with the duties and functions of training participants. In addition to the performance evaluation should be conducted to determine the performance of training participants graduated within a certain time after completing the training and return to the office.

2. Controlling by LAN-RI for the implementation of leadership training level IV should not only control the feedback, but expanded in the form of feed forward evaluation, and continuous control.

\section{REFERENCEES}

[1] Arikunto Suharsimi (2013), Dasar-Dasar Evaluasi Pendidikan, Edisi 2, Jakarta: Bumi Akasarab Chuk Williams. (2001).Management, Texas Cristian Univercity,Thomson Learning.Terjemahan M.Sabarudin Napitupulu. Jakarta: Salemba Empat

[2] Davis, Ivor K (1991), PengelolaanBelajar, Jakarta, Rajawali Press, DimyatidanMujiono (2010), BelajardanPembelajaran, cetakankeeempat, Jakarta: KerjasamaDepartemenPendidikandanKebudayaandengan PT RinekaCiptaDin Wahyudin. 2014. ManajemenKurikulum.Cetakanpertama. Bandung: PT.RemajaRosdaKarya Offset.

[3] HamalikOemar. (2008). Proses BelajarMengajar.Cetakankedelapan. Jakarta: BumiAksara

[4] Hasan BasridanRusdiana. (2015). Manajemenpendidikandanpelatihan

[5] Hussain Afzal et.al (2011), Evaluation Of Curriculum Developvement Process (2011), International Journal Of Humanities and Social Science, 1 (14); October 2011, 1

[6] L. Daft Richard (2008), Management, Terjemahan Edward TanujayadanShirlyTiolina, Jakarta: SalembaEmpat.

[7] MardaphiDjemari(2012)PengukuranpenilaiandanEvaluasiPendidikan,Cetakan1,Yogyakarta: NuhaMedika

[8] Mustari Mohammad, Ph.D. 2015. ManajemenPendidikan. Jakarta: PT RajagrafindoPersada

[9] PidatopengarahanGubernur Sumatera Utara Pada Acara PelaksanaanApelPagi di BadanDiklatProvsu, Senin, 15 April 2016.

[10] R.Terry George and W.Rue Leslie. 1982. Principles Of Management, four Edition. Printed in the United States of America.

[11] Rusman (2011), ManajemenKurikulum, PT raja GrafindoPersada, cetakanketiga, Jakarta

[12] Undang-UndangNomor 20 Tahun 2003 tentangSistemPendidikan Nasional 